\title{
Recent advances in understanding the molecular basis of
}

\section{melanogenesis in melanocytes [version 1; peer review: 2}

\section{approved]}

\author{
Norihiko Ohbayashi ${ }^{1}$, Mitsunori Fukuda (iD)2 \\ ${ }^{1}$ Faculty of Medicine and Graduate School of Comprehensive Human Sciences, University of Tsukuba, Tsukuba 305-8575, Japan \\ ${ }^{2}$ Laboratory of Membrane Trafficking Mechanisms, Department of Integrative Life Sciences, Graduate School of Life Sciences, \\ Tohoku University, Miyagi 980-8578, Japan
}

V1 First published: 15 Jun 2020, 9(F1000 Faculty Rev):608
https://doi.org/10.12688/f1000research.24625.1

Latest published: 15 Jun 2020, 9(F1000 Faculty Rev):608

https://doi.org/10.12688/f1000research.24625.1
Open Peer Review

Approval Status

1

2

version 1

15 Jun 2020

Faculty Reviews are review articles written by the prestigious Members of Faculty Opinions. The articles are commissioned and peer reviewed before publication to ensure that the final, published version is comprehensive and accessible. The reviewers who approved the final version are listed with their names and affiliations.

1. Subba Rao Gangi Setty, Indian Institute of Science, Bangalore, India

2. Santiago Di Pietro, Colorado State University, Fort Collins, USA

Any comments on the article can be found at the end of the article.

\section{Keywords}

BLOC, melanogenic enzymes, melanosome maturation, membrane traffic, Rab small GTPase 
Corresponding authors: Norihiko Ohbayashi (nohbayashi@md.tsukuba.ac.jp), Mitsunori Fukuda (nori@tohoku.ac.jp)

Author roles: Ohbayashi N: Conceptualization, Funding Acquisition, Writing - Original Draft Preparation, Writing - Review \& Editing; Fukuda M: Funding Acquisition, Writing - Original Draft Preparation, Writing - Review \& Editing

Competing interests: No competing interests were disclosed.

Grant information: This work was supported in part by Grant-in-Aid for Scientific Research (C) from the Ministry of Education, Culture, Sports, Science, and Technology (MEXT) of Japan (grant number 19 K06653 to N.O.), Grant-in-Aid for Scientific Research (B) from the MEXT (grant number $19 \mathrm{H} 03220$ to M.F.), and Japan Science and Technology Agency (JST) CREST (grant number JPMJCR17H4 to M.F.). The funders had no role in study design, data collection and analysis, decision to publish, or preparation of the manuscript.

Copyright: @ 2020 Ohbayashi N and Fukuda M. This is an open access article distributed under the terms of the Creative Commons Attribution License, which permits unrestricted use, distribution, and reproduction in any medium, provided the original work is properly cited.

How to cite this article: Ohbayashi $\mathrm{N}$ and Fukuda $\mathrm{M}$. Recent advances in understanding the molecular basis of melanogenesis in melanocytes [version 1; peer review: 2 approved] F1000Research 2020, 9(F1000 Faculty Rev):608

https://doi.org/10.12688/f1000research.24625.1

First published: 15 Jun 2020, 9(F1000 Faculty Rev):608 https://doi.org/10.12688/f1000research.24625.1 


\section{Introduction}

Melanin is the major pigment in mammalian skin and hair and is synthesized in specialized cells called melanocytes, which are present in the epidermis and in the matrix and outer root sheath of hair follicles. Melanin is present in the form of polymers formed from various indole compounds synthesized from the amino acid tyrosine. Two types of melanin are found in mammals: insoluble black eumelanin and soluble yellowreddish pheomelanin. Mammalian melanin is a complex of these two types of melanin, and their ratios are responsible for the differences in skin and hair color. Tyrosine is oxidized by the copper-containing enzyme tyrosinase and metabolized to dihydroxyphenylalanine (DOPA) and then to dopaquinone. Eumelanin and pheomelanin are formed by different metabolic pathways downstream of dopaquinone ${ }^{1}$. Since many of the intermediate molecules leading to melanin formation possess high redox toxicity, melanin synthesis is sequestered and executed in a specialized compartment, lysosome-related organelles called melanosomes ${ }^{2,3}$. Strictly speaking, melanogenesis refers to the process of melanin synthesis, but, more broadly, it includes the processes of melanosome formation, melanosome transport, melanosome transfer to keratinocytes, and melanin metabolism because these processes are also necessary for skin and hair pigmentation.

Melanosomes are classified into four stages according to their morphology and degree of pigment deposition ${ }^{3}$. Stage I melanosomes are typically early/sorting endosomes with clathrin coats and contain few intraluminal vesicles (ILVs). Physiological amyloid fibers are formed from ILVs by polymerization of processed premelanosome protein (PMEL), and they provide ellipsoidal shape to melanosomes and also serve as a scaffold for melanin pigmentation (stage II). Melanogenic enzymes, including tyrosinase, tyrosinase-related protein 1 (Tyrp1), and dopachrome tautomerase (Dct)/Tyrp2, are then transported to stage II melanosomes, and the melanosomes darken as melanin deposits on PMEL fibers (stages III and IV) $)^{2,3}$. This review article summarizes recent research topics related to melanosome formation and movements, with a special focus on the past 4 years.

\section{Melanosome biogenesis}

Transport of PMEL (also known as Pmel17 or gp100), a membrane protein, to immature melanosomes is an early step in melanosome biogenesis, but the mechanism by which it is achieved is not completely understood. PMEL is taken into the lumen of stage I immature melanosomes and proteolytically cleaved, a process that is required to form the fibrils that emanate from ILVs (Figure 1). This process requires the tetraspanin CD63, apolipoprotein E, and BACE2 ( $\beta$-secretase 2$)^{4,5}$. After PMEL fibril formation, the melanogenic enzymes are transported from the trans-Golgi network (TGN) or early endosomes to stage II immature melanosomes, and the melanin synthesized accumulates on the PMEL fibrils. The melanogenic enzymes are transported to the immature melanosomes via two endosomal pathways: a biogenesis of lysosome-associated organelles complex (BLOC)-1-dependent pathway and a BLOC1-independent/adaptor protein-3 (AP-3)-dependent pathway, although BLOC-1 is also physically and functionally associated with the AP-3-dependent pathway ${ }^{2,6}$. At steady state, BLOC-1 and AP-3 are thought to localize at distinct microdomains of early endosomes and to transport only partially overlapping melanosomal cargoes. BLOC-1 is a protein complex composed of eight subunits, including BLOC1 subunit 1 (BLOS1), BLOS2, BLOS3, Cappuccino/BLOC1S4, Muted/BLOC1S5, Pallidin/BLOC1S6, Snapin/BLOC1S7, and Dysbindin/BLOC1S8, that is initially localized on early endosomes and is essential for the formation of the transport carriers for melanosomal cargoes $^{3}$. BLOC-1 has been shown to associate with the kinesin3 motor and promote microtubule-dependent tubule formation, and then to cooperate with annexin A2 to form recycling endosomes by rearrangement of the actin cytoskeleton. Three of the BLOC1 subunits, BLOS1, BLOS2, and Snapin, are also present in another complex, BLOC-one-related complex (BORC), which regulates lysosomal centrifugal transport ${ }^{7}$, but the functions of BORC in melanogenesis remain to be determined ${ }^{8}$. UV radiation resistance-associated gene (UVRAG) is an adapter molecule that promotes autophagy and regulates energy homeostasis?, and it is also known to be involved in vitiligo ${ }^{10}$. UVRAG has recently been shown to bind to and stabilize several subunits of BLOC-1 (e.g. BLOS1 and Snapin), and melanosomal cargoes, such as tyrosinase and Tyrp1, are mis-trafficked and accumulate at early endosomes in UVRAG-deficient melanocytes. PMEL is also mis-trafficked in UVRAG-deficient melanocytes, but the mechanism of UVRAG-mediated PMEL trafficking is unknown ${ }^{11}$. However, since the UVRAGregulated BLOC1 subunits are also shared with BORC, further investigation is necessary to determine whether the UVRAG's role in melanosome cargo transport requires BLOC-1 or BORC.

Melanosomes are organelles that possess dynamic properties, and their lipid component is postulated to be involved in their membrane dynamics. Actually, melanosomes contain the phospholipid phosphatidylinositol 3,5-bisphosphate- $\mathrm{PI}(3,5) \mathrm{P}_{2}$ - which is specifically present in late endosomes/multivesicular bodies and lysosomes and regulates membrane trafficking between endo-lysosomes $^{12}$. $\mathrm{PI}(3,5) \mathrm{P}_{2}$ is synthesized from $\mathrm{PI}(3) \mathrm{P}$ by the phosphoinositide 5-kinase complex, which is composed of phosphoinositide kinase, FYVE-type zinc finger containing (PIKfyve), FIG4, and VAC14, and abnormal metabolism of $\mathrm{PI}(3,5) \mathrm{P}_{2}$ has been shown to be involved in hypopigmentation. A recent study reported that PIKfyve regulates the fusion of stage I melanosomes with lysosomes, a process that is involved in melanosome quality control ${ }^{13}$, and another group of researchers showed that PIKfyve regulates the trafficking of melanosomal cargoes to melanosomes as well as PMEL processing ${ }^{14}$. These findings suggest a role for PIKfyve in the formation of PMEL fibers and its organization in stage II melanosomes.

BLOC-2 is a protein complex composed of three subunits (HPS3, HPS5, and HPS6; the gene products responsible for Hermansky-Pudlak syndrome 3, 5, and 6, respectively). BLOC-2 localizes on early endosomes and on transport carriers like BLOC-1 and is postulated to function downstream of BLOC-1. Although the precise function of BLOC-2 remains 


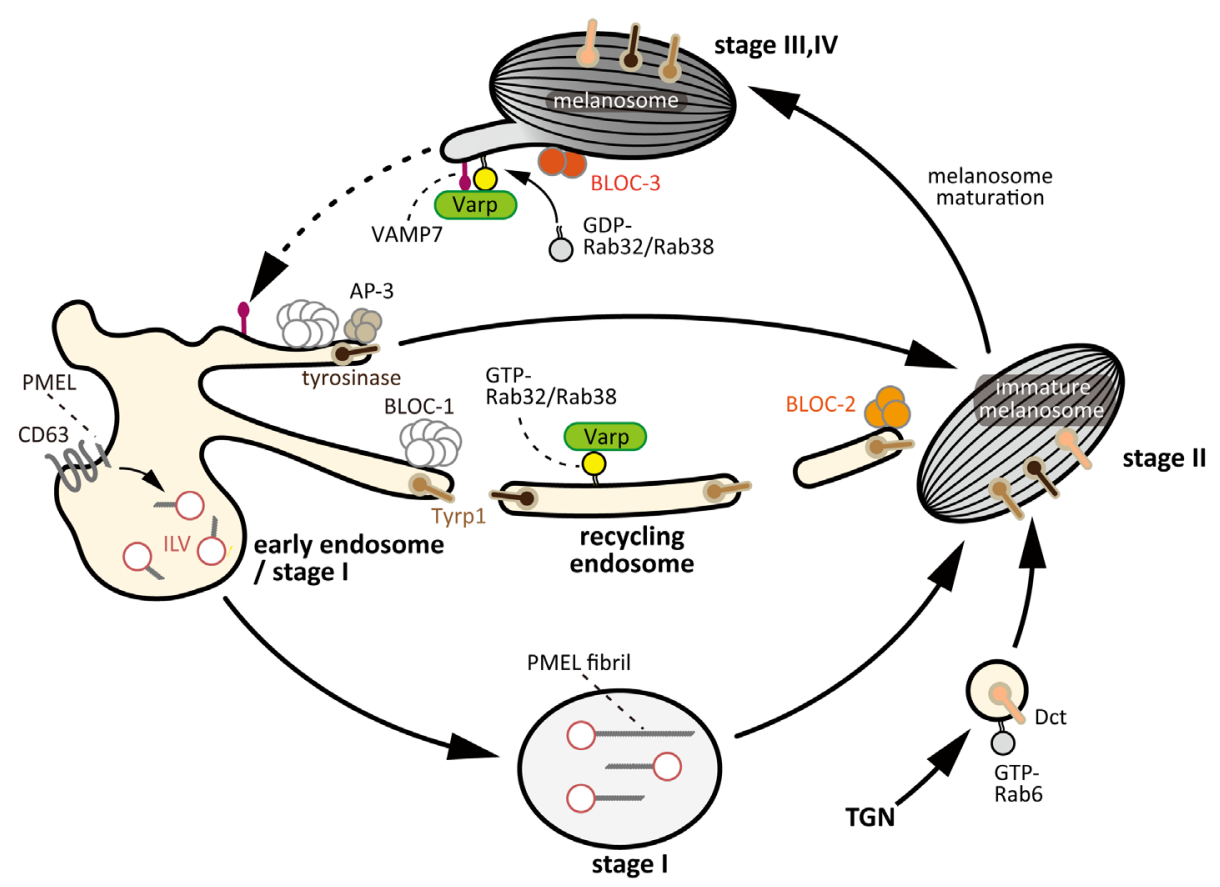

Figure 1. Schematic diagram of endosomal and melanosomal transport systems that have been proposed to regulate melanosome biogenesis. PMEL fibrils emanate from ILVs in the vacuolar portion of early endosomes, a process that requires the functions of CD63 and apolipoprotein E. The PMEL fibrils then form sheets onto which synthesized melanin is deposited. Melanosomal cargoes, including tyrosinase and Tyrp1, are secreted from the microdomains of early endosomes. Rab4A is postulated to regulate the segregation of the melanogenic enzymes from the vacuolar portion of the early endosomes ${ }^{15}$ (not depicted in this figure). The BLOC-1/2-dependent pathway regulates the transport of Tyrp1 and a small cohort of tyrosinase, and the AP-3-dependent pathway regulates the transport of a large cohort of tyrosinase. BLOC-1 is an important regulator in the formation of transport carriers in a microtubule- and actin-dependent manner. BLOC2 is involved in the fusion of transport carriers with maturing melanosomes, and BLOC-3 is required for the activation of Rab32/Rab38 on mature melanosomes. The Rab32/Rab38-Varp complex is required for the recovery of melanosomal cargoes, such as VAMP7, from mature melanosomes (retrograde trafficking), and is also required for the transport of melanogenic enzymes from early endosomes to maturing melanosomes (anterograde trafficking). The dotted arrow indicates an as-yet-unidentified transport pathway. AP, adaptor protein; BLOC, biogenesis of lysosome-related organelles complex; ILV, intraluminal vesicle; PMEL, premelanosome protein; TGN, trans-Golgi network; Tyrp1, tyrosinase-related protein 1; VAMP, vesicle-associated membrane protein; Varp, VPS9-ankyrin-repeat protein.

unknown, BLOC-2 is thought to tether the transport carriers to the melanosome membrane ${ }^{16}$. In addition, one of the endosomal Rabs, Rab22A, has been reported to promote the formation of the transport carriers from early endosomes by forming a complex with BLOC-1, BLOC-2, and the kinesin-3 motor $^{17}$.

Other subsets of Rabs with similar primary structures, Rab32 and $R a b 38^{18}$, are localized to the melanosome membrane and redundantly regulate melanosome biogenesis ${ }^{19}$. Rab32 and Rab38 are switch molecules that cycle between an active GTP-binding and an inactive GDP-binding form, the same as other Rabs (Figure 2). BLOC-3 is a heterodimeric protein complex composed of HPS1 and HPS4 and functions as a Rab32/Rab38-guanine nucleotide exchange factor $(\mathrm{GEF})^{20}$. In addition, HPS4 has been reported to be a potential effector molecule of Rab9 ${ }^{21}$. The Rab9-BLOC-3 axis was postulated to be involved in melanogenesis ${ }^{22}$, but it has been shown that the Rab32/Rab38-GEF activity of BLOC-3 is essential for melanogenesis and the Rab9 binding activity is not $^{23}$. The Rab32/Rab38 effector vacuolar protein sorting 9 (VPS9)-ankyrin repeat protein (Varp) is never recruited to melanosomes in BLOC-3-deficient melanocytes, and the trafficking of melanogenic enzymes, including tyrosinase, Tyrp1, and Dct, is impaired as a result ${ }^{2,23-26}$. The Rab32/Rab38-Varp complex has been thought to regulate anterograde transport of tyrosinase and Tyrp1 from early endosomes to melanosomes ${ }^{27}$; however, it has been shown to be utilized to recover another melanosomal cargo vesicle-associated membrane protein 7 (VAMP7) from mature melanosomes by cooperating with myosin VI $^{25}$ (Figure 1). The recovered VAMP7 is postulated to return to early endosomes for the next round of melanogenic enzyme transport. Rab32/Rab38 cycling is essential for the proper trafficking of melanogenic enzymes because the Rab32/Rab38-GTPase-activating protein (GAP) RUN and TBC1 domain-containing protein 1 (RUTBC1 [also known as small G-protein signaling modulator 2 (SGSM2)]) promotes melanogenic enzyme trafficking to melanosomes ${ }^{26}$. 


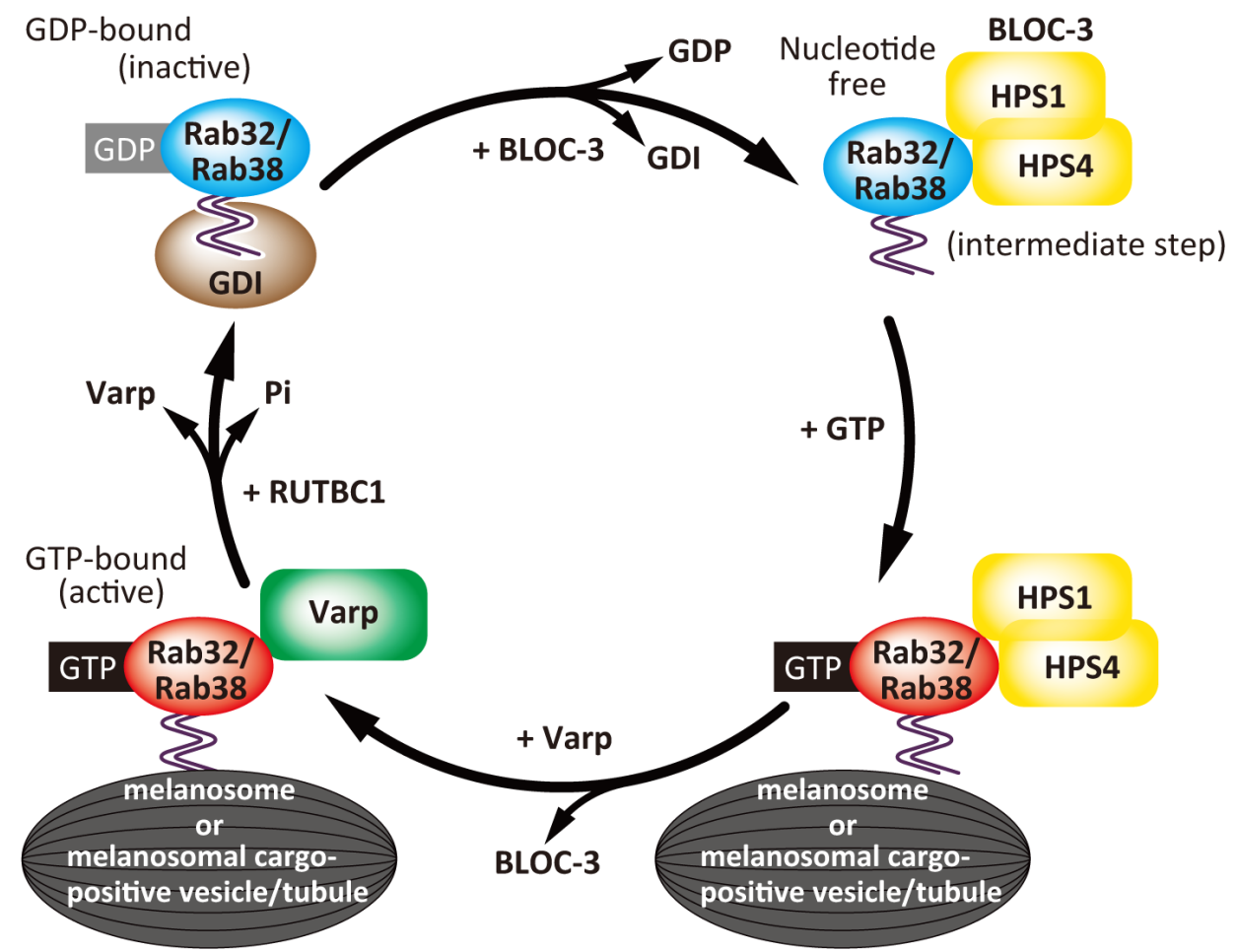

Figure 2. Diagram of Rab activation and inactivation during membrane traffic. Rabs are a subgroup of Ras-like small GTPases and are switch molecules that cycle between a GDP-binding inactive form and a GTP-binding active form. In this figure, Rab activation and inactivation mechanisms are shown by using Rab32 and Rab38 as examples. GDP-binding inactive Rab32 and Rab38 are present in the cytosol in complex with a GDI. BLOC-3 is a Rab32/Rab38-GEF that removes GDP from the GDP-Rab32/Rab38 and promotes their GTP binding, which converts Rab32/Rab38 to their active form. At the same time, Rab32/Rab38 are localized to the intracellular membrane surface by means of a geranylgeranyl group attached to the C-terminal cysteine residues of Rab32/Rab38. Active Rab32/Rab38 interact with one of their effector molecules, Varp, and regulate membrane trafficking, such as melanosomal cargo transport. The Rab32/Rab38-GAP RUTBC1 then activates the intrinsic GTPase activity of Rab32/Rab38, thereby hydrolyzing their GTP, and returning them to inactive GDP-Rab32/Rab38. BLOC, biogenesis of lysosome-related organelles complex; GAP, GTPase-activating protein; GDI, GDP dissociation inhibitor; GEF, guanine nucleotide exchange factor; HPS, Hermansky-Pudlak syndrome; RUTBC1, RUN and TBC1 domain-containing protein 1; Varp, VPS9-ankyrinrepeat protein.

Varp protein expression is considered to be essential for the correct transport of the melanogenic enzymes, and Rab40C and receptor for activated $\mathrm{C}$ kinase 1 (RACK1) have been shown to precisely regulate the amount of Varp via direct binding to the ankyrin repeat 2 (ANKR2) domain of Varp in a ubiquitination-dependent manner ${ }^{28-30}$. The involvement of Rab32/Rab38 in Dct trafficking appears to vary with the cell line $e^{26,31}$. Rab6 and its effector molecule, ELKS, have recently been suggested to mediate a pathway that may directly transport Dct from the TGN to melanosomes ${ }^{32}$. Future studies will elucidate how Rab32/Rab38 are required for Dct transport and the functional relationship between Rab32/Rab38- and Rab6-dependent pathways.

In addition to melanosomal structural proteins and melanogenic enzymes, certain transporters (or ion channels) are also required for melanogenesis to optimize luminal $\mathrm{pH}$ and concentration of other ions (e.g. $\mathrm{Cu}^{2+}$ and $\mathrm{Zn}^{2+}$ ) in melanosomes. Recently, functions of several transporters localized to the melanosome membrane have been revealed. Oculocutaneous albinism 2 (OCA2) and solute carrier 45 member 2 (SLC45A2, also known as MATP, membrane-associated transporter protein, or OCA4) are known to be the causative gene products of oculocutaneous albinism ${ }^{33,34}$. From fine analysis using a patch-clamp technique and a $\mathrm{pH}$ sensor protein on the melanosome membrane, OCA2 has been proposed to promote anion (e.g. $\mathrm{Cl}^{-}$) efflux from melanosomes to elevate their luminal $\mathrm{pH}$ (i.e. neutralization) ${ }^{33}$. SLC45A2 has also been shown to be involved in the neutralization of melanosomal $\mathrm{pH}$ by promoting $\mathrm{H}^{+}$-efflux from melanosomes ${ }^{34}$. Because tyrosinase is inactive below $\mathrm{pH}$ 6, OCA2 and SLC45A2 are thought to be essential transporters for promoting pigmentation. Two-pore channel 2 (TPC2) has also been associated with human pigmentation diseases ${ }^{35}$. TPC2 is postulated to pass cations such as $\mathrm{Na}^{+}$and $\mathrm{Ca}^{2+}$ across the melanosome membrane, and it has been shown that suppressing TPC2's function promotes pigmentation by raising the luminal $\mathrm{pH}$ in melanosomes ${ }^{36,37}$. Although which cation(s) transported by TPC 2 is responsible for acidification of melanosomes remains to be determined, $\mathrm{Na}^{+}$or $\mathrm{Ca}^{2+}$ efflux-mediated increase of melanosomal membrane potential has been proposed to modulate the function of vacuolar-type $\mathrm{H}^{+}$-ATPase (V-ATPase) to acidify melanosomes ${ }^{36,37}$. 
Thus, proper pigmentation would be achieved by the cooperative action of the neutralizing transporters (e.g. OCA2 and SLC45A2) and the acidifying transporters (e.g. TPC2) on the melanosome membrane.

\section{Melanosome movements in melanocytes}

The intracellular localization of mature melanosomes is regulated by coordinated transport activity in opposite directions on microtubules (i.e. long-range anterograde and retrograde microtubule-dependent transport) as well as shortrange anterograde transport on actin filaments ${ }^{2,38}$. Here we describe some recent findings with regard to the regulation of melanosome transport (Figure 3). Melanosome capturing by actin filaments and subsequent actin-based melanosome transport are regulated by a tripartite protein complex, Rab27ASlac2-a (also known as melanophilin [MLPH])-myosin Va, and abnormalities in the function of this complex cause Griscelli syndrome, a rare autosomal recessive hypopigmentation disease $^{2,38}$. MAP kinase activating death domain (MADD, also known as Rab3GEP or differentially expressed in normal and neoplastic cells [DENN]) had already been reported to be a Rab27A-GEF in melanocytes ${ }^{39}$. Re-analysis by the same

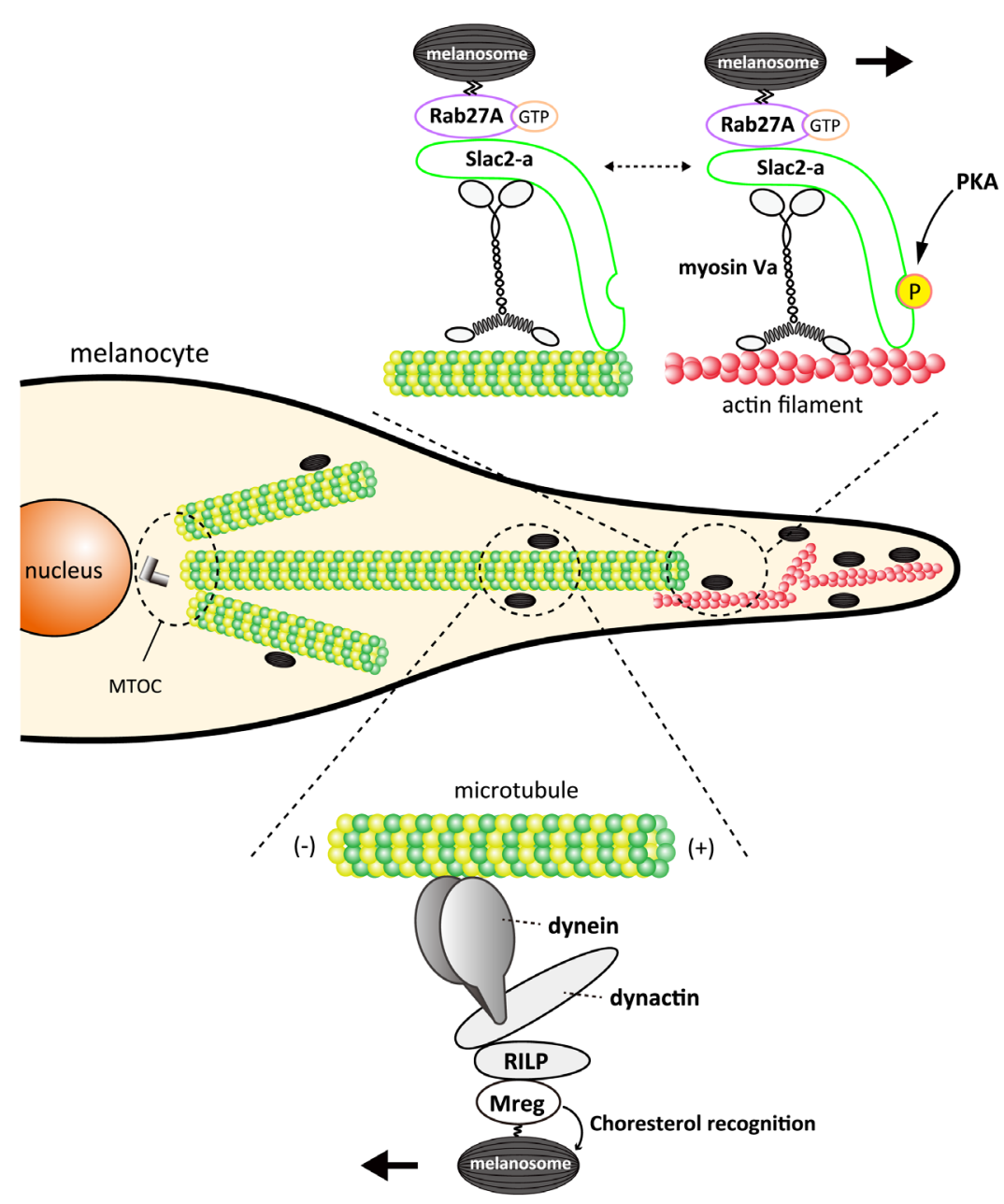

Figure 3. Mechanisms of mature melanosome transport along the cytoskeleton in melanocytes. Coordinated bidirectional movements along microtubules and unidirectional movement along actin filaments regulate the distribution of mature melanosomes within melanocytes, and the balance between microtubule-dependent retrograde transport and actin-dependent anterograde transport, in particular, is essential to the intracellular distribution of melanosomes. Mreg and Rab36 ${ }^{40}$ (not depicted in this figure) together with RILP, dynactin, and dynein play important roles in microtubule-dependent retrograde transport ${ }^{41}$, and the Rab27A-Slac2-a/MLPH-myosin Va complex plays an important role in actin-dependent anterograde transport. PKA mediates the phosphorylation of Slac2-a/MLPH and facilitates the Slac2-a/MLPH interaction with actin filaments, thereby promoting the actin-dependent melanosome transport ${ }^{42}$. In addition, phosphorylated Slac2-a/MLPH by PKA would also suppress the function of the dynein motor ${ }^{43}$. MLPH, melanophilin; Mreg, melanoregulin; PKA, protein kinase A; RILP, Rab-interacting lysosomal protein. 
group, however, showed that MADD/Rab3GEP/DENN functions as a Rab27A-GEF but is insufficient to activate Rab27A. Other Rab-GEFs, such as DENND4B and GRAB, presumably compensate for the function of MADD/Rab3GEP/DENN ${ }^{44}$.

Melanoregulin (Mreg) is a small protein with no conserved protein motifs and has been shown to be involved in retrograde melanosome transport along microtubules and in melanosome transfer to keratinocytes ${ }^{41,45}$. Its three-dimensional structure has recently been determined, and a tyrosine-based cholesterol recognition motif (CRAC motif) in Mreg has been found to be important to the retrograde transport of melanosomes along microtubules. Importantly, an Mreg mutant that lacks the CRAC motif does not promote the retrograde transport of melanosomes ${ }^{46}$. However, the precise molecular mechanism by which switching from microtubule-dependent to actin-dependent melanosome transport is regulated remains poorly understood. Phosphorylation of Slac2-a/MLPH may be one potential regulatory mechanism because, as a result of phosphorylation by protein kinase A (PKA), Slac2-a/MLPH has been shown to facilitate its interaction with actin filaments and PKA is important in determining the subcellular localization of melanosomes ${ }^{42,47}$. Moreover, zebrafish Slac2-a/MLPH has been suggested to suppress the function of dynein motor by cAMP- and PKA-dependent phosphorylation ${ }^{43}$. Thus, it is also interesting to investigate the functional regulation of molecules involved in retrograde melanosome transport along microtubules (e.g. Mreg, Rab-interacting lysosomal protein [RILP], dynactin, and dynein, depicted in Figure 3) by phosphorylation in mammalian melanocytes in the future.

\section{Perspectives}

We have summarized recent findings with regard to melanosome formation and movements in mammalian melanocytes. Fairly precise mechanisms for these events have gradually been demonstrated by recent elegant work conducted by various laboratories. However, achieving a comprehensive understanding of pigmentation in the broad sense will require elucidation of the mechanisms involved in the melanosome transfer process (i.e. the process of transferring melanosomes from melanocytes to keratinocytes or hair matrix cells) and melanin metabolism in keratinocytes, neither of which is fully understood. To date, at least four different models have been proposed for the melanosome transfer process: (i) melanosome-enriched dendrites of melanocytes, (ii) melanosome aggregates shed from dendrites, or (iii) exocytosed melanocores that are contained in melanosomes (i.e. melanosomes without their limiting membrane) are incorporated into keratinocytes by phagocytosis and/or endocytosis, and (iv) the two membranes of a melanocyte and a keratinocyte fuse, and melanosomes are transferred through the tubular structure formed between them. These models are summarized in recent reviews ${ }^{48-50}$. Live-cell bright-field observations and/or electron microscopic observations of melanocore and melanosome dynamics have been conducted to test these models, but bright-field imaging has the drawback of very low resolution of the spatial distribution of melanosomes, and electron microscopy can be performed on only fixed cells and thus cannot be used to make dynamic observations. Labeling melanin with a fluorescent probe should be a useful tool for making more accurate analyses of melanocore and melanosome dynamics in melanocytes and keratinocytes. Fortunately, we have been developing a fluorescent probe, melanocore-interacting Kif1c-tail (M-INK), that specifically recognizes melanocores and makes it possible to visualize the spatial distribution of incorporated melanosomes and melanocores in keratinocytes ${ }^{51}$. Using this probe has recently made it possible to identify Rab7B (also known as Rab42) as a key regulator that promotes melanosome protein degradation in keratinocytes ${ }^{52}$. Thus, the M-INK probe should be a useful tool for analyzing the metabolic pathway(s) of melanin in keratinocytes in the future.

\section{Abbreviations}

AP, adaptor protein; BLOC, biogenesis of lysosome-related organelles complex; BLOS, BLOC1 subunit; BORC, BLOCone-related complex; DENN, differentially expressed in normal and neoplastic cells; Dct, dopachrome tautomerase; GEF, guanine nucleotide exchange factor; HPS, Hermansky-Pudlak syndrome; ILV, intraluminal vesicle; MADD, MAP kinase activating death domain; M-INK, melanocore-interacting Kif1c-tail; MLPH, melanophilin; Mreg, melanoregulin; OCA2, oculocutaneous albinism 2; PKA, protein kinase A; PIKfyve, phosphoinositide kinase, FYVE-type zinc finger containing; $\mathrm{PI}(3,5) \mathrm{P}_{2}$, phosphatidylinositol 3,5-bisphosphate; PMEL, premelanosome protein; SLC45A2, solute carrier 45 member 2; TPC2, two-pore channel 2; TGN, trans-Golgi network; Tyrp1, tyrosinase-related protein 1; UVRAG, UV radiation resistance-associated gene; VAMP, vesicle-associated membrane protein; Varp, vacuolar sorting protein 9-ankyrin-repeat protein.

\section{Acknowledgements}

We thank members of the Fukuda laboratory for valuable discussions.
1. F Pavan WJ, Sturm RA: The genetics of human skin and hair pigmentation. Annu Rev Genomics Hum Genet. 2019; 20: 41-72. PubMed Abstract | Publisher Full Text | Faculty Opinions Recommendation

2. Ohbayashi N, Fukuda M: SNARE dynamics during melanosome maturation. Biochem Soc Trans. 2018; 46(4): 911-7. PubMed Abstract | Publisher Full Text
3. $\quad \mathrm{F}$ Bowman SL, Bi-Karchin J, Le L, et al:: The road to lysosome-related organelles: Insights from Hermansky-Pudlak syndrome and other rare diseases. Traffic. 2019; 20(6): 404-35. PubMed Abstract | Publisher Full Text | Free Full Text | Faculty Opinions Recommendation

4. van Niel G, Bergam P, Di Cicco A, et al.: Apolipoprotein E regulates amyloid 
formation within endosomes of pigment cells. Cell Rep. 2015; 13(1): 43-51. PubMed Abstract | Publisher Full Text

5. F McGlinchey RP, Lee JC: Why study functional amyloids?: Lessons from the repeat domain of Pmel17. J Mol Biol. 2018; 430(20): 3696-706.

PubMed Abstract | Publisher Full Text | Free Full Text |

Faculty Opinions Recommendation

6. Di Pietro SM, Falcón-Pérez JM, Tenza D, et al:: BLOC-1 interacts with BLOC-2 and the AP-3 complex to facilitate protein trafficking on endosomes. $\mathrm{Mol} \mathrm{Biol}$ Cell. 2006; 17(9): 4027-38.

PubMed Abstract | Publisher Full Text | Free Full Text

7. $\quad \mathrm{F}$ Pu J, Schindler C, Jia R, et al.: BORC, a multisubunit complex that regulates lysosome positioning. Dev Cell. 2015; 33(2): 176-88.

PubMed Abstract | Publisher Full Text | Free Full Text |

Faculty Opinions Recommendation

8. Chen T, Song G, Yang H, et al.: Development of the swimbladder surfactant system and biogenesis of lysosome-related organelles is regulated by BLOS 1 in zebrafish. Genetics. 2018; 208(3): 1131-46.

PubMed Abstract | Publisher Full Text | Free Full Text

9. Liang C, Feng P, Ku B, et al.: UVRAG: A new player in autophagy and tumor cell growth. Autophagy. 2007; 3(1): 69-71.

PubMed Abstract | Publisher Full Tex

10. Jeong TJ, Shin MK, Uhm YK, et al:: Association of UVRAG polymorphisms with susceptibility to non-segmental vitiligo in a Korean sample. Exp Dermatol. 2010; 19(8): e323-5.

PubMed Abstract | Publisher Full Text

11. $F$ Yang $Y$, Jang GB, Yang $X$, et al:: Central role of autophagic UVRAG in melanogenesis and the suntan response. Proc Natl Acad Sci U S A. 2018; 115(33): E7728-37.

PubMed Abstract | Publisher Full Text | Free Full Text |

Faculty Opinions Recommendation

12. Hasegawa J, Strunk BS, Weisman LS: PI5P and PI(3,5) $\mathbf{P}_{2}$ : Minor, but essential phosphoinositides. Cell Struct Funct. 2017; 42(1): 49-60. PubMed Abstract | Publisher Full Text | Free Full Text

13. $\mathrm{F}$ Bissig $\mathrm{C}$, Croisé $\mathrm{P}$, Heiligenstein $\mathrm{X}$, et al:: The PIKfyve complex regulates the early melanosome homeostasis required for physiological amyloid formation. J Cell Sci. 2019; 132(5): jcs229500.

PubMed Abstract | Publisher Full Text | Free Full Text

Faculty Opinions Recommendation

14. F Liggins MC, Flesher JL, Jahid S, et al:: PIKfyve regulates melanosome biogenesis. PLoS Genet. 2018; 14(3): e1007290.

PubMed Abstract | Publisher Full Text | Free Full Text |

Faculty Opinions Recommendation

15. F Nag S, Rani S, Mahanty S, et al.: Rab4A organizes endosomal domain for sorting cargo to lysosome-related organelles. J Cell Sci. 2018; 131(18): jcs216226.

PubMed Abstract | Publisher Full Text | Free Full Text

Faculty Opinions Recommendation

16. Dennis MK, Mantegazza AR, Snir OL, et al:: BLOC-2 targets recycling endosomal tubules to melanosomes for cargo delivery. J Cell Biol. 2015; 209(4): 563-77. PubMed Abstract | Publisher Full Text | Free Full Text

17. F Shakya S, Sharma P, Bhatt AM, et al:: Rab22A recruits BLOC-1 and BLOC-2 to promote the biogenesis of recycling endosomes. EMBO Rep. 2018; 19(12): e45918.

PubMed Abstract | Publisher Full Text | Free Full Text

Faculty Opinions Recommendation

18. Ohbayashi N, Fukuda M, Kanaho Y: Rab32 subfamily small GTPases: Pleiotropic Rabs in endosomal trafficking. J Biochem. 2017; 162(2): 65-71. PubMed Abstract | Publisher Full Text

19. F Wasmeier $\mathrm{C}$, Romao M, Plowright $\mathrm{L}$, et al:: Rab38 and Rab32 control postGolgi trafficking of melanogenic enzymes. J Cell Biol. 2006; 175(2): 271-81. PubMed Abstract | Publisher Full Text | Free Full Text |

Faculty Opinions Recommendation

20. Gerondopoulos A, Langemeyer L, Liang JR, et al:: BLOC-3 mutated in Hermansky-Pudlak syndrome is a Rab32/38 guanine nucleotide exchange factor. Curr Biol. 2012; 22(22): 2135-9.

PubMed Abstract | Publisher Full Text | Free Full Text

21. Kloer DP, Rojas R, Ivan V, et al.: Assembly of the biogenesis of lysosomerelated organelles complex-3 (BLOC-3) and its interaction with Rab9. J Bio Chem. 2010; 285(10): 7794-804

PubMed Abstract | Publisher Full Text | Free Full Text

22. Mahanty S, Ravichandran K, Chitirala $\mathrm{P}$, et al.: Rab9A is required for delivery of cargo from recycling endosomes to melanosomes. Pigment Cell Melanoma Res. 2016; 29(1): 43-59.

PubMed Abstract | Publisher Full Text | Free Full Text

23. Ohishi $Y$, Kinoshita R, Marubashi S, et al:: The BLOC-3 subunit HPS4 is required for activation of Rab32/38 GTPases in melanogenesis, but its Rab9 activity is dispensable for melanogenesis. J Biol Chem. 2019; 294(17): 6912-22. PubMed Abstract | Publisher Full Text | Free Full Text

24. Fukuda M: Multiple roles of VARP in endosomal trafficking: Rabs, retromer components and R-SNARE VAMP7 meet on VARP. Traffic. 2016; 17(7): 709-19. PubMed Abstract | Publisher Full Text

25. Dennis MK, Delevoye C, Acosta-Ruiz A, et al: BLOC-1 and BLOC-3 regulate
VAMP7 cycling to and from melanosomes via distinct tubular transport carriers. J Cell Biol. 2016; 214(3): 293-308.

PubMed Abstract | Publisher Full Text | Free Full Text

26. Marubashi S, Shimada H, Fukuda M, et al.: RUTBC1 functions as a GTPaseactivating protein for Rab32/38 and regulates melanogenic enzyme trafficking in melanocytes. J Biol Chem. 2016; 291(3): 1427-40.

PubMed Abstract | Publisher Full Text | Free Full Text

27. Bultema JJ, Ambrosio AL, Burek CL, et al.: BLOC-2, AP-3, and AP-1 proteins function in concert with Rab38 and Rab32 proteins to mediate protein trafficking to lysosome-related organelles. J Biol Chem. 2012; 287(23): 19550-63.

PubMed Abstract | Publisher Full Text | Free Full Text

28. Yatsu A, Shimada H, Ohbayashi N, et al.: Rab40C is a novel Varp-binding protein that promotes proteasomal degradation of Varp in melanocytes. Biol Open. 2015; 4(3): 267-75.

PubMed Abstract | Publisher Full Text | Free Full Text

29. Marubashi S, Ohbayashi N, Fukuda M: A Varp-binding protein, RACK1, regulates dendrite outgrowth through stabilization of Varp protein in mouse melanocytes. J Invest Dermatol. 2016; 136(8): 1672-80.

PubMed Abstract | Publisher Full Text

30. F Day JP, Whiteley E, Freeley M, et al.: RAB40C regulates RACK1 stability via the ubiquitin-proteasome system. Future Sci OA. 2018; 4(7): FSO317. PubMed Abstract | Publisher Full Text | Free Full Text | Faculty Opinions Recommendation

31. Bultema JJ, Boyle JA, Malenke PB, et al:: Myosin Vc interacts with Rab32 and Rab38 proteins and works in the biogenesis and secretion of melanosomes. J Biol Chem. 2014; 289(48): 33513-28. PubMed Abstract | Publisher Full Text | Free Full Text

32. Patwardhan A, Bardin S, Miserey-Lenkei S, et al.: Routing of the RAB6 secretory pathway towards the lysosome related organelle of melanocytes. Nat Commun 2017; 8: 15835.

PubMed Abstract | Publisher Full Text | Free Full Text

33. Bellono NW, Escobar IE, Lefkovith AJ, et al:: An intracellular anion channel critical for pigmentation. eLife. 2014; 3: e04543.

PubMed Abstract | Publisher Full Text | Free Full Text

34. Bin BH, Bhin J, Yang SH, et al:: Membrane-associated transporter protein (MATP) regulates melanosomal $\mathrm{pH}$ and influences tyrosinase activity. PLOS One. 2015; 10(6): e0129273.

PubMed Abstract | Publisher Full Text | Free Full Text

35. Sulem $P$, Gudbjartsson DF, Stacey SN, et al.: Two newly identified genetic determinants of pigmentation in Europeans. Nat Genet. 2008; 40(7): 835-7. PubMed Abstract | Publisher Full Text

36. Ambrosio AL, Boyle JA, Aradi AE, et al:: TPC2 controls pigmentation by regulating melanosome pH and size. Proc Natl Acad SciU S A. 2016; 113(20): $5622-7$.

PubMed Abstract | Publisher Full Text | Free Full Text

37. Bellono NW, Escobar IE, Oancea E: A melanosomal two-pore sodium channel regulates pigmentation. Sci Rep. 2016; 6: 26570. PubMed Abstract | Publisher Full Text | Free Full Text

38. Ohbayashi N, Fukuda M: Role of Rab family GTPases and their effectors in melanosomal logistics. J Biochem. 2012; 151(4): 343-51. PubMed Abstract | Publisher Full Text

39. Tarafder AK, Wasmeier C, Figueiredo AC, et al:: Rab27a targeting to melanosomes requires nucleotide exchange but not effector binding. Traffic. 2011; 12(8): 1056-66.

PubMed Abstract | Publisher Full Text | Free Full Text

40. Matsui T, Ohbayashi N, Fukuda M: The Rab interacting lysosomal protein (RILP) homology domain functions as a novel effector domain for small GTPase Rab36: Rab36 regulates retrograde melanosome transport in melanocytes. $J$ Biol Chem. 2012; 287(34): 28619-31. PubMed Abstract | Publisher Full Text | Free Full Text

41. Ohbayashi $\mathrm{N}$, Maruta $\mathrm{Y}$, Ishida $\mathrm{M}$, et al.: Melanoregulin regulates retrograde melanosome transport through interaction with the RILP-p150 Glued complex in melanocytes. J Cell Sci. 2012; 125(6): 1508-18.

PubMed Abstract | Publisher Full Text

42. Oberhofer $A$, Spieler $P$, Rosenfeld $Y$, et al:: Myosin Va's adaptor protein melanophilin enforces track selection on the microtubule and actin networks in vitro. Proc Natl Acad Sci U S A. 2017; 114(24): E4714-23. PubMed Abstract | Publisher Full Text | Free Full Text

43. F sheets L, Ransom DG, Mellgren EM, et al:: Zebrafish melanophilin facilitates melanosome dispersion by regulating dynein. Curr Biol. 2007; 17(20): 1721-34. PubMed Abstract | Publisher Full Text | Free Full Text | Faculty Opinions Recommendation

44. F Sanzà P, Evans RD, Briggs DA, et al:: Nucleotide exchange factor Rab3GEP requires DENN and non-DENN elements for activation and targeting of Rab27a. J Cell Sci. 2019; 132(9): jcs212035.

PubMed Abstract | Publisher Full Text | Free Full Text | Faculty Opinions Recommendation

45. F Wu XS, Masedunskas A, Weigert R, et al.: Melanoregulin regulates a shedding mechanism that drives melanosome transfer from melanocytes to keratinocytes. Proc Natl Acad Sci U S A. 2012; 109(31): E2101-9. PubMed Abstract | Publisher Full Text | Free Full Text |

Faculty Opinions Recommendation 
46. F Rout AK, Wu X, Starich MR, et al: The structure of melanoregulin reveals a role for cholesterol recognition in the protein's ability to promote dynein function. Structure. 2018; 26(10): 1373-83.

PubMed Abstract | Publisher Full Text | Free Full Text | Faculty Opinions Recommendation

47. F Oberhofer A, Reithmann E, Spieler $\mathrm{P}$, et al.: Molecular underpinnings of cytoskeletal cross-talk. Proc Natl Acad Sci U S A. 2020; 117(8): 3944-52. PubMed Abstract | Publisher Full Text | Free Full Text | Faculty Opinions Recommendation

48. Wu X, Hammer JA: Melanosome transfer: It is best to give and receive. Curr Opin Cell Biol. 2014; 29: 1-7.

PubMed Abstract | Publisher Full Text | Free Full Text
49. Tadokoro R, Takahashi $\mathrm{Y}$ : Intercellular transfer of organelles during body pigmentation. Curr Opin Genet Dev. 2017; 45: 132-8. PubMed Abstract | Publisher Full Text

50. F Tadokoro R, Shikaya $\mathrm{Y}$, Takahashi $\mathrm{Y}$ : Wide coverage of the body surface by melanocyte-mediated skin pigmentation. Dev Biol. 2019; 449(2): 83-9. PubMed Abstract | Publisher Full Text | Faculty Opinions Recommendation

51. Ishida M, Marubashi S, Fukuda M: M-INK, a novel tool for visualizing melanosomes and melanocores. J Biochem. 2017; 161(4): 323-6. PubMed Abstract | Publisher Full Text

52. Marubashi S, Fukuda M: Rab7B/42 is functionally involved in protein degradation on melanosomes in keratinocytes. Cell Struct Funct. 2020; 45(1): 45-55.

PubMed Abstract | Publisher Full Text 


\section{Open Peer Review}

\section{Current Peer Review Status:}

\section{Editorial Note on the Review Process}

Faculty Reviews are review articles written by the prestigious Members of Faculty Opinions. The articles are commissioned and peer reviewed before publication to ensure that the final, published version is comprehensive and accessible. The reviewers who approved the final version are listed with their names and affiliations.

\section{The reviewers who approved this article are:}

\section{Version 1}

\section{Santiago Di Pietro}

Department of Biochemistry and Molecular Biology, Colorado State University, Fort Collins, CO, USA Competing Interests: No competing interests were disclosed.

\section{Subba Rao Gangi Setty}

Department of Microbiology \& Cell Biology, Indian Institute of Science, Bangalore, India

Competing Interests: No competing interests were disclosed.

The benefits of publishing with F1000Research:

- Your article is published within days, with no editorial bias

- You can publish traditional articles, null/negative results, case reports, data notes and more

- The peer review process is transparent and collaborative

- Your article is indexed in PubMed after passing peer review

- Dedicated customer support at every stage

For pre-submission enquiries, contact research@f1000.com 